\title{
Effects of MK801 on evoked potentials, spinal cord blood flow and cord edema in acute spinal cord injury in rats
}

\author{
$\mathrm{S} \mathrm{Li}^{1,2}$ and $\mathrm{CH}$ Tator*,1,2 \\ ${ }^{1}$ Division of Neurosurgery, Toronto Western Hospital and University of Toronto, Toronto, M5T 2S8 Canada; \\ ${ }^{2}$ Canadian Paraplegic Association Spinal Cord Injury Research Laboratory, Toronto Western Hospital and University \\ of Toronto, Toronto, M5T 2S8 Canada
}

\begin{abstract}
Objectives: To determine whether MK801, an NMDA receptor antagonist, blocks glutamate excitotoxicity directly or via other mechanisms such as improving blood supply at the injury site in a rat model of spinal cord injury (SCI). In the present study, the effects of pre- and posttreatment with MK801 on axonal function, spinal cord blood flow (SCBF) and cord water content were studied after acute SCI in rats.

Methods: Somatosensory evoked potentials (SSEPs) and cerebellar evoked potentials (CEPs) were used to quantify electrophysiological function, and the hydrogen clearance technique and wet-dry weight measurements were used to measure SCBF and cord water content, respectively. Twenty rats received a $21 \mathrm{~g}$ clip compression injury of the cord at $\mathrm{T} 1$, and were then randomly and blindly allocated to either MK801 or saline groups. Each rat received an intravenous infusion of drug or saline four times during the experiment (16 min/infusion) with the first infusion (MK801 $3 \mathrm{mg} / \mathrm{kg}$ ) beginning 8 min pre-injury, and the other infusions $(\mathrm{MK} 8011.5 \mathrm{mg} / \mathrm{kg}$ ) at $1 \mathrm{~h}$ intervals after injury. Control experiments on uninjured rats were performed in 10 rats using the same procedure as above except the clip compression injury of the cord was omitted.

Results: In the MK801 groups with or without SCI, the amplitude of the evoked potential peaks, especially the SSEPs, was significantly lower than in the saline group. There were no differences in SCBF or cord water content between the MK801 and saline groups.

Conclusion: Pre- and posttreatment with MK801 inhibits evoked potentials, but does not improve SCBF or cord edema after acute compression SCI in rats. For the first time it has been shown that MK801 produced a blockade of glutamate excitatory transmission in afferent pathways after SCI. Further work is required to determine whether this inhibition is reversible and related to neuroprotection and functional recovery after SCI.
\end{abstract}

Keywords: evoked potentials; MK801; NMDA; spinal cord blood flow; spinal cord injury; water content

\section{Introduction}

The excitatory amino acid (EAA) neurotransmitter glutamate is considered to play a pivotal role in the pathogenesis of neuronal death due to ischemia or trauma in the central nervous system. ${ }^{1}$ There is increasing evidence that EAA-mediated processes contribute significantly to the progressive neuronal loss in these conditions. The mechanisms of EAAmediated injury to neurons including major ionic shifts have been identified in in vitro and in vivo preparations. ${ }^{2-5}$ For example, glutamate not only caused early intracellular accumulation of sodium and chloride ions

*Correspondence: CH Tator, Division of Neurosurgery, Toronto Western Hospital, 399 Bathurst Street, Toronto, Ontario, M5T 2S8, Canada resulting in acute cytotoxic edema, it also caused an early intracellular influx of extracellular calcium ions resulting in delayed damage of neurons. ${ }^{2,6}$ There are several subtypes of glutamate receptors and among these, the N-methyl-D-aspartic acid (NMDA), 1amino-3-hydroxy-5-methyl-4-isoxazole-propionic acid (AMPA), and kainic acid (KA) receptors are especially important in inducing neurotoxicity. ${ }^{7}$ There is evidence that acute spinal cord injury ( $\mathrm{SCI}$ ) causes damage by two separate mechanisms: the initial mechanical disruption, and secondary damage due to a variety of vascular and biochemical processes, ${ }^{8}$ such as increased levels of intracellular $\mathrm{Ca}^{2+},{ }^{9-12}$ liberation of free fatty acids, uncontrolled production of free radicals, phospholipid degradation and abnormalities in prostaglandin production. ${ }^{13-15}$ Since 1985 , it has 
been known that there are NMDA and AMPA/KA receptors in the spinal cord and that local damage is induced when sufficiently high concentrations of glutamate or its agonists are injected into the spinal subarachnoid space. ${ }^{16-19}$ Furthermore, SCI increases the tissue levels of glutamate and aspartate at the site of injuries. ${ }^{13,20}$

Treatment with glutamate receptor antagonists can reduce neurotoxicity and provide neuroprotection following SCI. (+)5-methyl-10,11-dihydro-5H-dibenzo[a,b] cyclohepten-5,10-imine maleate (MK801), a glutamate receptor antagonist, produces a noncompetitive use-dependent blockade of the NMDA receptor, which appears to mediate the lethal intracellular influx of calcium ions responsible for the neurotoxic effects of glutamate. However, treatment of experimental SCI in rats with MK801 has produced variable results. For example, MK801, administered systemically before or after SCI produced by the weight drop method, improved long-term neurologic recovery and reduced pathological changes and alterations in certain tissue cations, ${ }^{21,22}$ consistent with the hypothesis that NMDA receptors mediate certain pathophysiologic changes and secondary cord damage after SCI. In contrast, MK801 did not improve neurologic function or spinal cord blood flow (SCBF) after a compressive injury. ${ }^{23}$

To study the therapeutic value of MK801 in SCI in the present experiments, somatosensory evoked potentials (SSEPs) were used to monitor the dorsal columns, while cerebellar evoked potentials (CEPs) were used to assess conduction in the ventral spinal cord. $^{24}$ SSEPs and CEPs accurately reflect axonal function in the ascending tracts of spinal cord, and serial recordings after acute SCI provide information concerning the extent of the lesion and are an index of predicting functional outcome. ${ }^{24-26}$ SSEP measurement several hours after acute SCI has been used as a predictor of final behavioral recovery, which can take 4 weeks or more to become stable. ${ }^{27,28}$ Changes in evoked potential amplitude correlate with severity of the SCI and posttraumatic ischemia, and the latter is reversible by pharmacological intervention. Increase in SCBF at the site of SCI correlates with improvement in the function of acutely injured spinal axons, ${ }^{25,29}$ and glutamate signaling may play a role in modulation of blood flow and blood brain barrier permeability. ${ }^{30}$ Therefore, we hypothesize that treatment with an NMDA antagonist after acute SCI would affect axonal function by blocking NMDA receptors and reducing neurotoxicity at the injury site, and that there would be an increase in blood flow and a decrease in edema in the injured spinal cord. ${ }^{31-33}$ To test these hypotheses, we observed the effects of pre- and posttreatment with MK801 on the axonal conduction, posttraumatic ischemia and cord edema by measuring evoked potentials, SCBF and cord water content, respectively, after acute compression SCI in rats.

\section{Materials and methods}

\section{Animal preparation}

Thirty adult male Wistar rats (mean weight $378 \pm 22.4 \mathrm{~g}$, range $340-430 \mathrm{~g}$ ) were anesthetized by intraperitoneal injection of a-chloralose $(75 \mathrm{mg} / \mathrm{kg})$ and urethane $(525 \mathrm{mg} / \mathrm{kg})$, and then a tracheostomy was performed. Both femoral veins and the right femoral artery were cannulated. The left sciatic nerve was exposed under the biceps femoris and a bipolar stimulating electrode, consisting of two non-cutting stainless steel acupuncture needles (25 gauge) separated by $1 \mathrm{~mm}$, was inserted directly into the sciatic nerve. A small piece of cork served to insulate the protruding ends on the other side of the nerve.

With the aid of an operating microscope, a small burr hole was placed over the right sensorimotor cortex, $3 \mathrm{~mm}$ caudal to the coronal suture and $1 \mathrm{~mm}$ lateral to the sagittal suture, and a second burr hole was made over the paramedian lobule of the left cerebellar hemisphere, $2 \mathrm{~mm}$ inferior and $2 \mathrm{~mm}$ lateral to the external occipital protuberance. A ball-shaped platinum recording electrode $0.8 \mathrm{~mm}$ in diameter was placed extradurally into each burr hole. Both recording electrodes were referenced to an $\mathrm{Ag} / \mathrm{AgCl}$ disc electrode inserted between the tongue and hard palate. A platinum needle electrode was inserted in the upper thoracic paraspinal musculature for grounding.

Muscle relaxation was produced by intravenous injection of $0.7 \mathrm{mg}$ pancuronium bromide followed by $0.4 \mathrm{mg}$ every $30 \mathrm{~min}$. Ventilation was maintained with a mixture of $1: 2$ nitrous oxide and oxygen by a Harvard rodent ventilator (Model 683, South Natick, MA, USA). A continuous intravenous infusion of a mixture of $0.9 \%$ sodium chloride, $5 \%$ albumin and $2 \%$ sodium bicarbonate was given at a rate of $7.0 \mathrm{ml} /$ $\mathrm{kg} / \mathrm{h}$ during the experiment to maintain blood pressure. Blood gases, mean arterial pressure (MAP), rectal temperature and haematocrit (HCT) were monitored throughout the experiment. Body temperature (BT) was maintained at $37-38^{\circ} \mathrm{C}$ with a heating pad, and blood gases were maintained in the physiological range $\left(\mathrm{pH} 7.35-7.45 ; \mathrm{PCO}_{2} \quad 35-\right.$ $45 \mathrm{mmHg} ; \mathrm{PO}_{2}>150 \mathrm{mmHg}$ ).

A laminectomy was performed at $\mathrm{T}_{1}$ and $\mathrm{C}_{7}$ with the aid of an operating microscope, and the dura covering the dorsal aspect of the spinal cord was incised and retracted laterally. The injury was made with the extradural clip compression technique at $\mathrm{T}_{1}{ }^{34}$ (20 rats). The clip closure force was $21 \mathrm{~g}$, and the duration of compression was $1 \mathrm{~min}$. For the uninjured controls (10 rats), the same surgical preparation was applied except omission of clip compression to spinal cord.

\section{Evoked potentials}

The techniques for measuring the SSEPs and CEPs were similar to those reported previously from this laboratory. ${ }^{24,29,35}$ The SSEPs and CEPs were recorded 
simultaneously on a Cadwell 8400 signal averager (Cadwell Laboratories Inc., Kennewich, WA, USA) with a sweep time of $90 \mathrm{msec}$. The bandpass filter was set for $30-3000 \mathrm{~Hz}$, and the stimulation rate was $4.2 \mathrm{~Hz}$ at a current of 5 mamp and 50 us duration. Two hundred responses were averaged and replicated at least once for each record. The latency of the CEP and SSEP peaks was measured from the onset of stimuli to the peak of each wave, and the amplitude of the evoked potential waves was measured from the peak of one polarity to the immediately preceding peak of the opposite polarity. The amplitude of the initial wave was determined from the preceding baseline to the wave peak.

\section{Measurement of spinal cord blood flow}

SCBF was measured by the hydrogen clearance technique with a microcomputer-based recording system described in detail in previous reports from this laboratory. ${ }^{36,37}$ Two platinum-iridium microelectrodes with a $10 \mathrm{um}$ tip diameter, straddled the midline dorsal vein $(0.5 \mathrm{~mm}$ lateral to the midline $)$, and were stereotactically inserted into the dorsal column of the spinal cord to a depth of $500 \mathrm{um}$ at $\mathrm{T}_{1}$. After a period for electrode stabilization, $5-7 \%$ hydrogen was administered through the ventilator until saturation was reached after which $\mathrm{SCBF}$ recording commenced with the hydrogen clearance curves recorded during the desaturation phase. Linear regression was used online to compare the presaturation polarographic baseline level with the desaturation baseline level. Flows with a drift in baseline measurement of more than $5 \%$ were discarded. The initial slope index method was used to calculate the SCBF from the logarithmically transformed desaturation curves.

\section{Measurement of water content}

At the end of the recording session (approximately $4.5 \mathrm{~h}$ after injury), the rats were sacrificed by bolus injection of sodium pentobarbital. Immediately after the injured and adjacent segments of the spinal cord (6.6-12.1 g) extending $1 \mathrm{~mm}$ beyond the border of the grossly haemorrhagic cord were removed, weighed on aluminium foil, dried at $105^{\circ} \mathrm{C}$ for $24 \mathrm{~h}$, and reweighed. The percent water content was calculated as follows:

$$
\text { water content }(\%)=\frac{\text { wet weight dry weight }}{\text { wet weight }} \times 100
$$

\section{Experimental protocol}

MK801 was dissolved in a vehicle solution of $0.9 \%$ saline. Thirty animals were randomly divided into four groups, the SCI with or without MK801 (10 rats/ group) and uninjured controls with or without drug treatment ( 5 rats/group). The treatment group received MK801 at a dose of $3 \mathrm{mg} / \mathrm{kg}$ in the first infusion and $1.5 \mathrm{mg} / \mathrm{kg}$ in the following three infusions (total $7.5 \mathrm{mg} / \mathrm{kg}$ ), while the control group received only saline. All the animals were allocated randomly to one of the four groups before experiments, and the injuries were made without knowledge of the group to which an individual animal belonged.

After the initial surgical preparation including the laminectomy, CEPs, SSEPs and SCBF were recorded. Then $0.5 \mathrm{ml}$ of MK801 solution or saline was infused intravenously over 16 min using a Harvard infusion/ withdrawal pump. At the 8th minute of infusion, the injury was made at the $T_{1}$ segment. Five minutes after injury, CEPs and SSEPs were recorded again. The first posttreatment SCBF measurement started at the end of the first drug or saline infusion. After each of the subsequent three infusions of drug or saline, the SSEP, CEP and SCBF recordings were repeated at an interval of $1 \mathrm{~h}$ from the last infusion or recording. After completion of the last $\mathrm{SCBF}$ recording, the rats were sacrificed and the injured spinal cord was removed for assessment of water content.

\section{Statistical analysis}

The data were evaluated blindly and the treatment code was not broken until the conclusion of the statistical analysis. Comparisons at each time point between groups were made by univariate one-way analysis of variance (ANOVA), whereas comparisons within each group at different times were made by paired $t$-test. A stabilizing transformation (square root) of the evoked potential amplitude data was performed prior to parametric analysis. The results were expressed as the mean \pm SEM (standard error of the mean), and the differences were considered significant at $P<0.05$.

\section{Results}

\section{SCI experiments}

Physiological parameters The mean preinjury physiological parameters including MAP, HCT, $\mathrm{pH}, \mathrm{PCO}_{2}$, $\mathrm{PO}_{2}$ and BT were not significantly different $(P>0.05)$ between treatment and control groups (Table 1). Furthermore, paired $t$-test showed that the $\mathrm{pH}, \mathrm{BT}$, $\mathrm{PCO}_{2}$ and $\mathrm{PO}_{2}$ remained constant throughout the experiment $(P>0.05)$. Although the pre- and postinjury haematocrit was similar between treatment and control groups $(P>0.05)$, the postinjury mean haematocrit of both groups was significantly lower than the preinjury values $(P<0.01$, Table 1$)$.

After spinal cord injury, the MAP decreased significantly in both groups (Table 1 and Figure 1), and then recovered partially $1 \mathrm{~h}$ later. However, one way ANOVA revealed that the post-injury MAP in the treatment group was significantly lower than in the control group at $5 \mathrm{~min}, 2 \mathrm{~h}$ and $3 \mathrm{~h}$ postinjury $(P<0.05)$.

Cerebellar evoked potentials Preinjury, the amplitude and latency of each CEP peak (N1, P1, N2 and P2) 
Table 1 Physiological parameters*

\begin{tabular}{lcccccc}
\hline Groups & $M A P(\mathrm{mmHg})$ & $\mathrm{HCT}(\%)$ & $p H$ & $B T\left({ }^{\circ} \mathrm{C}\right)$ & $\mathrm{PO}_{2}(\mathrm{mmHg})$ & $\mathrm{PCO}(\mathrm{mmHg})$ \\
\hline MK-1h & $113.0 \pm 3.1$ & $38.2 \pm 1.1$ & $7.37 \pm 0.096$ & $37.4 \pm 0.10$ & $241.7 \pm 9.3$ & $40.0 \pm 0.5$ \\
Sal-1h & $113.6 \pm 4.3$ & $38.0 \pm 1.1$ & $7.37 \pm 0.009$ & $37.6 \pm 0.09$ & $228.9 \pm 9.2$ & $38.9 \pm 0.9$ \\
MK5m & $47.0 \pm 1.4^{* *}$ & $33.5 \pm 0.5^{* *}$ & $7.39 \pm 0.059$ & $37.1 \pm 0.14$ & $223.3 \pm 8.8$ & $36.9 \pm 0.5$ \\
Sal5m & $87.1 \pm 3.7^{* *}$ & $35.9 \pm 1.4^{* *}$ & $7.39 \pm 0.011$ & $37.2 \pm 0.16$ & $226.2 \pm 8.7$ & $37.3 \pm 0.7$ \\
MK1h & $77.0 \pm 4.8^{* *}$ & $32.9 \pm 1.0^{* *}$ & $7.40 \pm 0.009$ & $37.2 \pm 0.06$ & $229.2 \pm 6.5$ & $39.0 \pm 0.8$ \\
Sallh & $87.0 \pm 4.5^{* *}$ & $33.3 \pm 1.0^{* *}$ & $7.39 \pm 0.010$ & $37.4 \pm 0.47$ & $217.8 \pm 5.6$ & $37.7 \pm 0.8$ \\
MK2h & $71.7 \pm 4.0^{* *}$ & $30.8 \pm 0.9^{* *}$ & $7.40 \pm 0.009$ & $37.2 \pm 0.09$ & $222.6 \pm 9.2$ & $38.6 \pm 0.1$ \\
Sal2h & $87.7 \pm 5.5^{* *}$ & $32.0 \pm 1.4^{* *}$ & $7.40 \pm 0.008$ & $37.4 \pm 0.18$ & $224.3 \pm 5.3$ & $37.0 \pm 0.4$ \\
MK3h & $69.0 \pm 0.9^{* *}$ & $29.0 \pm 0.5^{* *}$ & $7.40 \pm 0.009$ & $37.3 \pm 0.13$ & $215.2 \pm 6.9$ & $38.6 \pm 0.9$ \\
Sal3h & $86.7 \pm 5.1^{* *}$ & $30.8 \pm 1.2^{* *}$ & $7.39 \pm 0.007$ & $37.4 \pm 0.19$ & $221.1 \pm 6.9$ & $39.9 \pm 0.8$ \\
MK4h & $71.8 \pm 5.1^{* *}$ & $28.7 \pm 1.0^{* *}$ & $7.40 \pm 0.077$ & $37.1 \pm 0.10$ & $212.2 \pm 5.5$ & $39.8 \pm 0.9$ \\
Sal4h & $81.8 \pm 4.6^{* *}$ & $29.1 \pm 0.9^{* *}$ & $7.39 \pm 0.008$ & $37.3 \pm 0.16$ & $218.4 \pm 4.9$ & $40.6 \pm 0.6$ \\
\hline
\end{tabular}

*Values are means \pm standard error of the means. ${ }^{* *} P<0.01$. Comparison between pre- and postinjury within each group ( $n=10$ per group). $\mathrm{MK} 1 \mathrm{~h}=1 \mathrm{~h}$ preinjury in MK801 group; Sall h $=1 \mathrm{~h}$ preinjury in saline group; MK $5 \mathrm{~m}=5 \mathrm{~min}$ postinjury in MK801 group; Sal5m $=5 \mathrm{~min}$ postinjury in saline group; $\mathrm{MK} 1 \mathrm{~h}=1 \mathrm{~h}$ postinjury in MK801 group; Sall $\mathrm{h}=1 \mathrm{~h}$ postinjury in saline group; MK2h=2 h postinjury in MK801 group; Sal2h=2 h postinjury in saline group; MK $3 \mathrm{~h}=3 \mathrm{~h}$ postinjury in MK801 group; $\mathrm{Sal} 3 \mathrm{~h}=3 \mathrm{~h}$ postinjury in saline group; $\mathrm{MK} 4 \mathrm{~h}=4 \mathrm{~h}$ postinjury in MK801 group; Sal $4 \mathrm{~h}=4 \mathrm{~h}$ postinjury in saline group

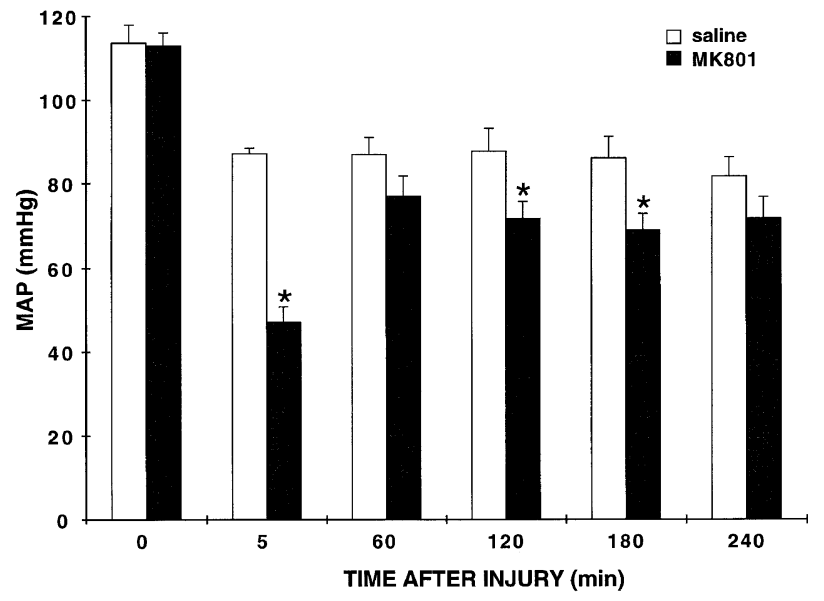

Figure 1 Mean systemic arterial blood pressure (MAP) recorded at different times. The preinjury MAP did not differ significantly between the two groups. Following SCI, there was a significant decrease in MAP in both groups. The decrease in the MK801 group was more significant than in the saline group at $5 \mathrm{~min}, 2 \mathrm{~h}$ and $3 \mathrm{~h}$ postinjury $(P<0.05$, $n=10$ per group, $*=$ the difference between the saline and MK801 groups is statistically significant)

were not significantly different between the MK801 and control groups. As shown in Figure 2, the amplitude of the N1, P1 peaks decreased significantly after SCI $(P<0.01, t$-test $)$. The late components of the CEPs, N2 and P2, disappeared by $5 \mathrm{~min}$ postinjury. At $1 \mathrm{~h}$ postinjury, the return of the $\mathrm{N} 2$ and $\mathrm{P} 2$ waves was observed in two and one rats respectively in the MK801 group, and in four and three rats respectively in the control group. Although the amplitude of N1

\section{CEREBELLAR EVOKED POTENTIALS}

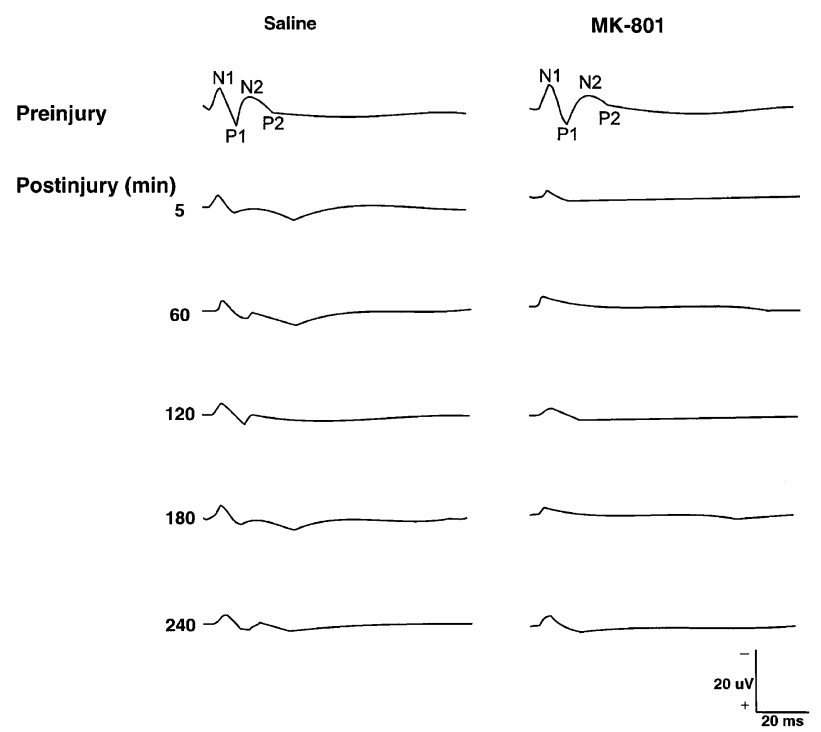

Figure 2 Cerebellar evoked potential recordings from two rats, one from each of the saline and MK801 groups. Before SCI, the amplitude of the CEP peaks was similar between the two rats. Five minutes after SCI, it decreased significantly in both animals. From $1-4 \mathrm{~h}$ postinjury, the CEP amplitude partly recovered in the rat receiving saline, but remained low in the rat treated with $\mathrm{MK} 801$

and P1 was lower in the MK801 group than in the control group after SCI, one-way ANOVA revealed that only the reduction in $\mathrm{N} 1$ amplitude at $1 \mathrm{~h}$ postinjury was statistically significant $(P<0.05$, Figure 3). 
Preinjury, the latency of each CEP peak did not differ significantly between the two groups, and there were no significant differences after injury $(P>0.05)$.

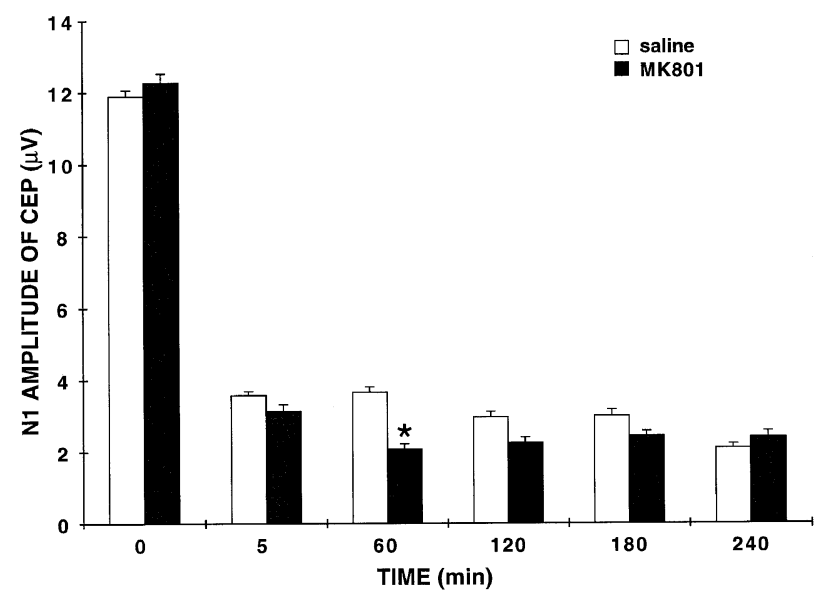

Figure 3 The amplitude of N1 peak of CEPs at different times. Preinjury, the N1 amplitude was similar in both groups. After SCI, there was a more significant attenuation of the amplitude of N1 peak in the MK801 group at $1 \mathrm{~h}$ postinjury in comparison with the saline group $(P<0.05$, $n=10$ per group, $*=$ the difference between the saline and MK801 groups is statistically significant)

\section{SOMATOSENSORY EVOKED POTENTIALS}

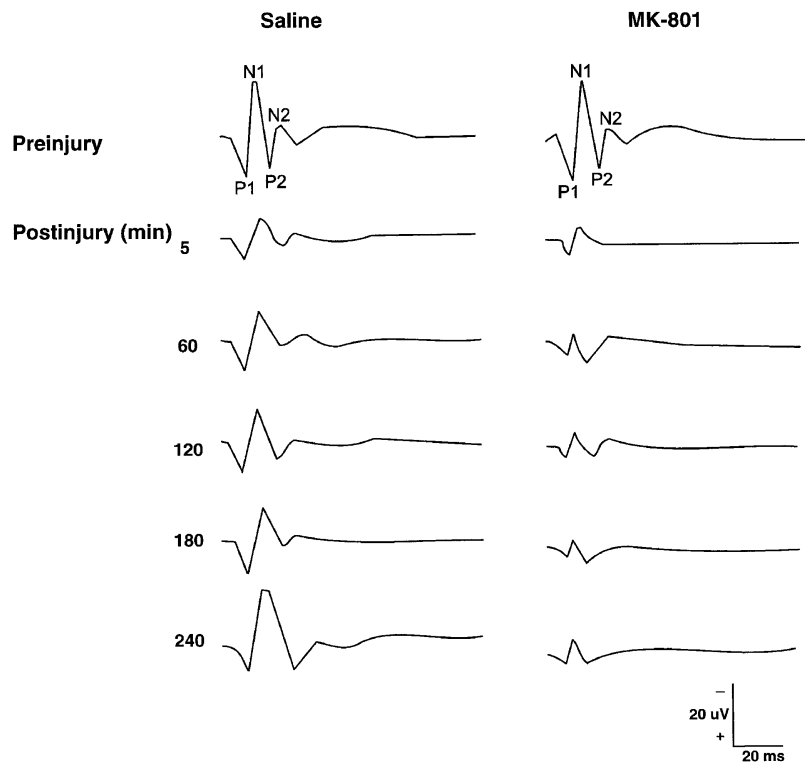

Figure 4 Somatosensory evoked potential recordings from two rats, one from each side of the saline and MK801 groups. Before SCI, the amplitude of each SSEP peak was similar between the two rats. Five minutes after SCI, it decreased significantly in both animals. From $1-4 \mathrm{~h}$ postinjury, the SSEP amplitude partly recovered in the rat receiving saline, but remained low in the rat treated with MK801
Somatosensory evoked potentials Preinjury, the amplitude and latency of each SSEP peak were not significantly different between the two groups (Figure 4). The amplitude of these peaks decreased significantly after SCI $(P<0.01, t$-test), but one-way ANOVA revealed that the amplitude attenuation of these peaks $(\mathrm{P} 1, \mathrm{~N} 1$ and $\mathrm{P} 2)$ was greater in the MK801 group $(P<0.01$, Figure $5 \mathrm{~A}-\mathrm{C})$. Recovery of the amplitude was observed in the control group $(P<0.05)$ at $1,2,3$ and $4 \mathrm{~h}$ postinjury in comparison with the value at

A

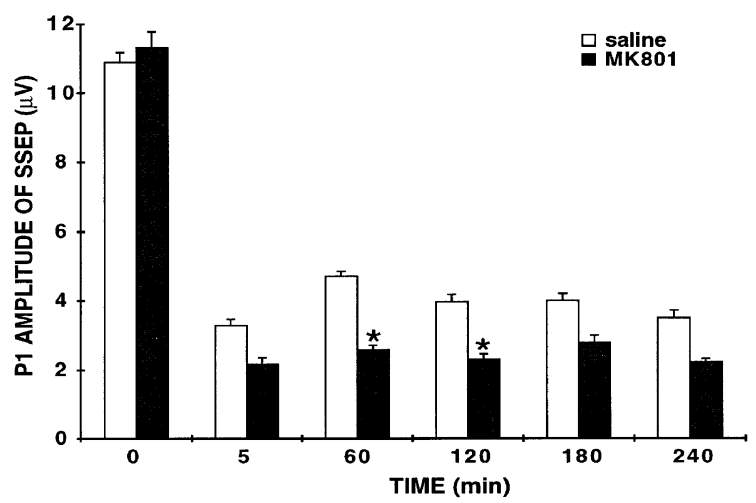

B

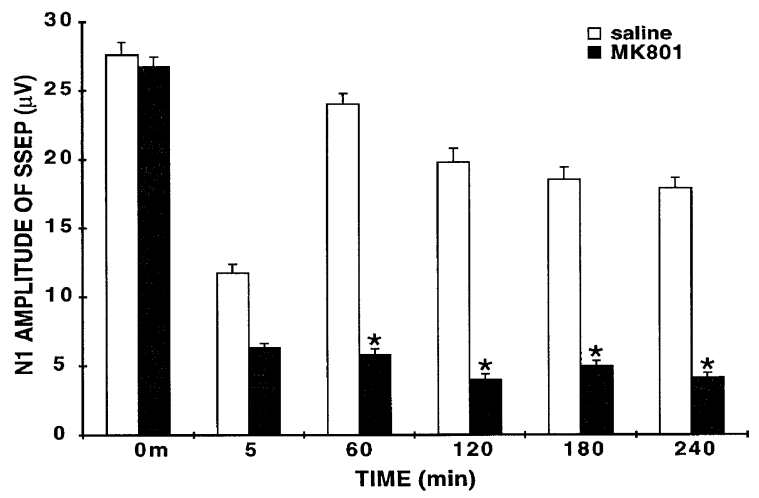

C

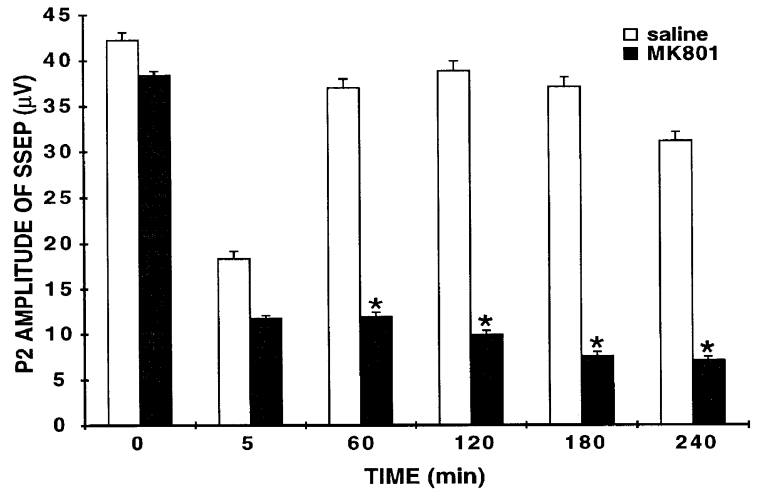

Figure 5 Effect of MK801 on the amplitude of P1 (A), N1 (B) and P2 (C) peaks of SSEPs. Preinjury, the amplitude of these peaks was similar in both groups. After SCI, there was a more significant decrease of $\mathrm{P} 1, \mathrm{~N} 1$ and $\mathrm{P} 2$ amplitude in the MK801 group than in the saline group, particularly in N1 and $\mathrm{P} 2$ amplitude. $(P<0.01, n=10$ per group, $*=$ the difference between the saline and MK801 groups is statistically significant) 
5 min postinjury. In contrast, the amplitude of each peak remained low in the MK801 group after SCI $(P>0.05)$. The $t$-test and one-way ANOVA indicated that the latency of each peak did not change significantly within each group or between the two groups $(P>0.05)$.

Table 2 Mean values of SCBF and postinjury SCBF decrease (mean \pm SEM) during the experiment. The SCBF decreased significantly after SCI $(n=10$ per group)

\begin{tabular}{llc}
\hline Groups\# & \multicolumn{1}{c}{ SCBF } & SCBF decrease \\
\hline MK1h & $71.8 \pm 4.2$ & \\
Sal1h & $76.3 \pm 6.6$ & \\
MK5m & $40.0 \pm 5.2^{* *}$ & $33.3 \pm 3.4$ \\
Sal5m & $44.0 \pm 5.2^{* *}$ & $33.4 \pm 5.2$ \\
MK1h & $37.7 \pm 1.9^{* *}$ & $33.9 \pm 3.4$ \\
Sal1h & $41.4 \pm 4.6^{* *}$ & $35.0 \pm 4.9$ \\
MK2h & $33.6 \pm 2.7^{* *}$ & $39.7 \pm 3.0$ \\
Sal2h & $44.0 \pm 4.6^{* *}$ & $35.3 \pm 3.9$ \\
MK3h & $35.9 \pm 3.2^{* *}$ & $37.5 \pm 3.1$ \\
Sal3h & $37.4 \pm 3.9^{* *}$ & $38.3 \pm 3.2$ \\
MK4h & $38.3 \pm 3.3^{* *}$ & $38.9 \pm 4.6$ \\
Sal4h & $37.5 \pm 3.5^{* *}$ & $38.9 \pm 4.6$ \\
\hline
\end{tabular}

$* * P<0.01$ comparison between pre- and postinjury within each group. SCBF: $\mathrm{ml} / \mathrm{min} / 100 \mathrm{~g}$. \#The group designations are described in Table 1
Spinal cord blood flow The pre- and postinjury SCBF was similar in the two groups (Table 2). Although there was a significant decrease in SCBF after SCI $(P<0.01, t$-test $)$, the decrease was similar in the two groups. After SCI, the SCBF remained consistently low during the experiment in both groups $(P>0.05)$.

Water content Although there was a slight reduction in the MK801 group, one-way ANOVA revealed that there was no significant difference in water content (Df $=1,17 ; \mathrm{F}=0.559 ; P=0.4649$ ) between the MK801 group $(75.7 \% \pm 1.3)$ and the control group $(77.8 \% \pm 2.5)$

\section{Uninjured controls}

Before and after infusion, the mean physiological parameters including MAP, HCT, $\mathrm{PH}, \mathrm{PCO}_{2}, \mathrm{PO}_{2}$ and BT were not significantly different $(P>0.05)$ between the MK801 and saline groups except that MAP in the MK801 group was slightly lower than in the control group at 13 min after infusion (95 vs $105 \mathrm{mmHg}: P<0.05)$. Before infusion, the amplitude of each CEP or SSEP peak was not significantly different between MK801 and control groups, but there was a statistical reduction in N1 amplitude of CEP, and P1, N1 and P2 amplitude of SSEP in the MK801 group compared with the saline group following drug infusion (Figure $6 \mathrm{~A}-\mathrm{D}, P<0.05$ or 0.01 ). In addition
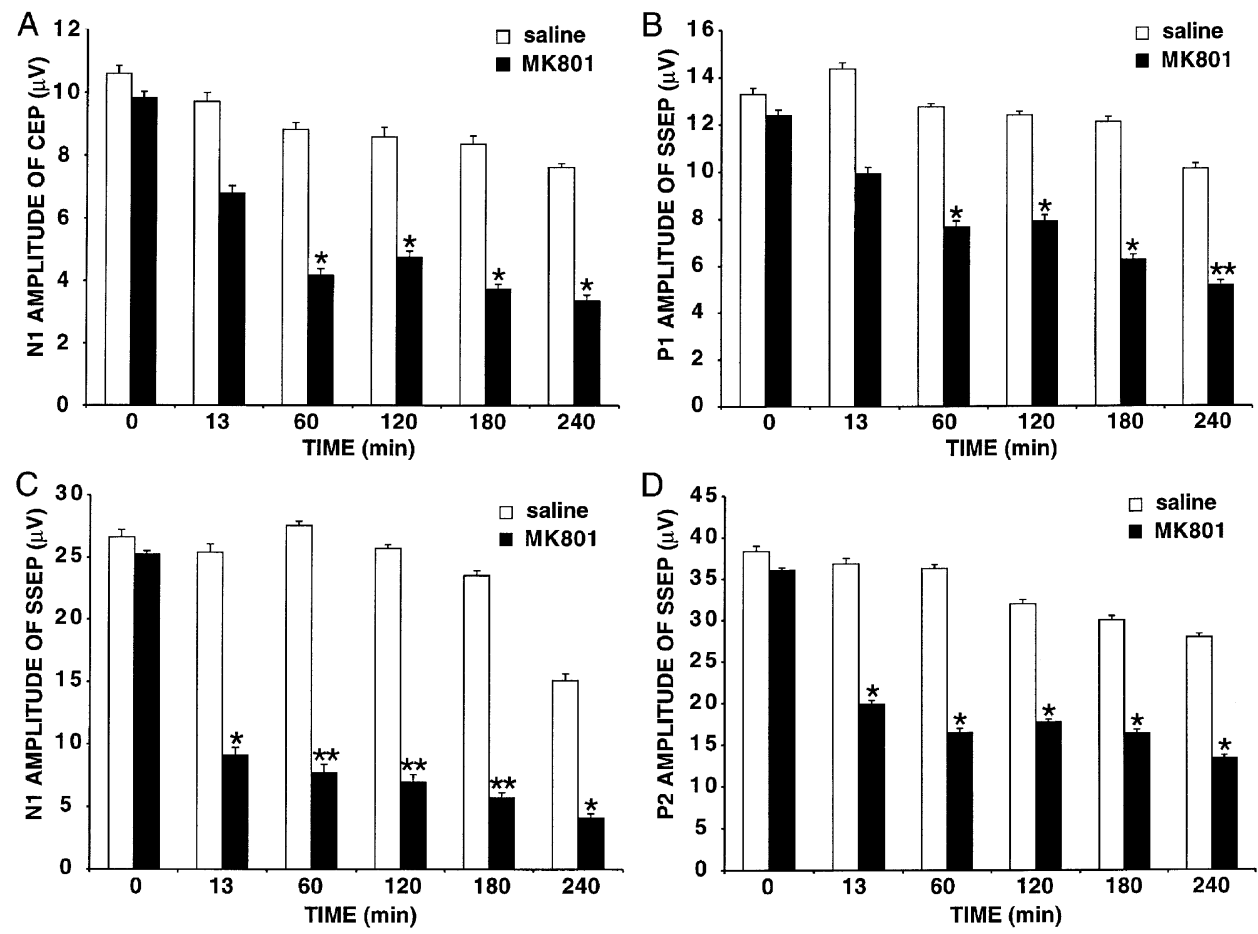

Figure 6 Effect of MK801 on the amplitude of each peak of CEPs and SSEPs in uninjured controls. The amplitude of N1 (A) peak of CEP and P1 (B), N1 (C) and P2 (D) peaks of SSEP was similar between MK801 and saline groups before infusion. Intravenous injection of MK801 caused a significant amplitude reduction in these peaks in comparison with saline controls. $(* P<0.05 ; * * P<0.01, n=5$ per group) 
Table 3 Effects of MK801 on recovery after in vivo SCI

\begin{tabular}{|c|c|c|c|c|c|c|}
\hline & Authors & Administration & Injury model & $\begin{array}{l}\text { Observation } \\
\text { time }\end{array}$ & Outcome measures & Results \\
\hline \multirow[t]{2}{*}{$\begin{array}{l}\text { Acute } \\
\text { studies }\end{array}$} & $\begin{array}{l}\text { Li and Taylor } \\
\text { (present study) }\end{array}$ & $\begin{array}{l}3 \mathrm{mg} / \mathrm{kg} \text { iv, prior } \\
\text { to and after } \\
\mathrm{SCI}(1.5 \mathrm{mg} / \mathrm{kg} \\
\times 3)\end{array}$ & $\begin{array}{l}\text { rats, clip } \\
\text { compression }\end{array}$ & $4 \mathrm{~h}$ & $\begin{array}{l}\text { multiple evoked } \\
\text { potentials, spinal } \\
\text { cord blood flow } \\
\text { water content }\end{array}$ & $\begin{array}{l}\text { reduced the amplitude of } \\
\text { evoked potentials, did not } \\
\text { affect spinal cord blood flow } \\
\text { or water content at injured } \\
\text { site }\end{array}$ \\
\hline & $\begin{array}{l}\text { Haghighi et al } \\
(1996)^{48}\end{array}$ & $\begin{array}{l}1 \mathrm{mg} / \mathrm{kg} \text {, iv, } \\
15 \mathrm{~min} \text { prior to } \\
\mathrm{SCI}\end{array}$ & $\begin{array}{l}\text { rats, weight } \\
\text { compression }\end{array}$ & $5 \mathrm{~h}$ & $\begin{array}{l}\text { somatosensory } \\
\text { evoked potential } \\
\text { and morphology }\end{array}$ & $\begin{array}{l}\text { improved evoked potential } \\
\text { recovery, reduced } \\
\text { hemorrhage and } \\
\text { neurofilament damage }\end{array}$ \\
\hline \multirow[t]{5}{*}{$\begin{array}{l}\text { Chronic } \\
\text { studies }\end{array}$} & $\begin{array}{l}\text { Faden et al } \\
(1988)^{21}\end{array}$ & $\begin{array}{l}0.2-5.0 \mathrm{mg} / \mathrm{kg} \\
\text { iv, } 15 \mathrm{~min} \text { after } \\
\text { SCI }\end{array}$ & rats, weight-drop & 30 days & $\begin{array}{l}\text { behavior, } \\
\text { neuroanatomy, } \\
\text { water content, } \\
\text { tissue cations }\end{array}$ & $\begin{array}{l}\text { improved neurologic } \\
\text { function, decreased } \\
\text { histologic damage, no } \\
\text { change in cord edema }\end{array}$ \\
\hline & $\begin{array}{l}\text { Gomez-Pinilla } \\
\text { et al }(1989)^{22}\end{array}$ & $\begin{array}{l}0.3 \mathrm{mg} / \mathrm{kg}, \text { ip, } \\
60 \mathrm{~min} \text { before } \\
\text { SCI }\end{array}$ & rats, weight drop & 30 days & behavior, histology & $\begin{array}{l}\text { improved neurologic } \\
\text { function and decreased } \\
\text { neuronal death }\end{array}$ \\
\hline & $\begin{array}{l}\text { Hao et al } \\
(1992)^{44}\end{array}$ & $\begin{array}{l}0.1-1.0 \mathrm{mg} / \mathrm{kg} \text {, } \\
\text { iv, } 30 \mathrm{~min} \\
\text { before SCI }\end{array}$ & rats, laser & 21 days & behavior, histology & $\begin{array}{l}\text { decreased neurologic deficit } \\
\text { and spinal cord necrosis }\end{array}$ \\
\hline & $\begin{array}{l}\text { Holtz et al } \\
(1991)^{23}\end{array}$ & $\begin{array}{l}10 \mathrm{mg} / \mathrm{kg}, \mathrm{iv}, \\
60 \mathrm{~min} \text { after SCI }\end{array}$ & rats, compression & 4 days & $\begin{array}{l}\text { spinal cord blood } \\
\text { flow and behavior }\end{array}$ & $\begin{array}{l}\text { no improvement in SCBF or } \\
\text { behavior }\end{array}$ \\
\hline & $\begin{array}{l}\text { Yanase } \\
\text { et al }(1995)^{33}\end{array}$ & $\begin{array}{l}5 \mathrm{mg} / \mathrm{kg}, \mathrm{iv}, \\
10 \mathrm{~min} \text { after } \mathrm{SCI}\end{array}$ & $\begin{array}{l}\text { rabbits, } \\
\text { compression }\end{array}$ & 14 days & $\begin{array}{l}\text { behavior, } \mathrm{SCBF} \text {, } \\
\text { water content }\end{array}$ & $\begin{array}{l}\text { improved motor function } \\
\text { and cord edema, but not } \\
\text { SCBF }\end{array}$ \\
\hline
\end{tabular}

MK801 infusion did not have any significant effects on SCBF during the $4 \mathrm{~h}$ observation $(50.0 \pm 8.6$ vs $46.7 \pm 3.8 \mathrm{ml} / \mathrm{min} / 100 \mathrm{~g}$ for the last measurement $(P<0.05, t$-test $)$.

\section{Discussion}

Several studies have shown a rapid elevation of the extracellular concentration of glutamate and aspartate in traumatic ${ }^{38,39}$ and ischemic ${ }^{40}$ spinal cord lesions consistent with the hypothesis that these lesions are associated with a release of these excitatory amino acids at the lesion site. In the weight-drop model, Demediuk et al (1989) observed increased extracellular glutamate and aspartate as early as $5 \mathrm{~min}$ after SCI and found that the release of these amino acids was delayed, time-dependent and related to the severity of injury. ${ }^{13}$ Similarly, in a compression model, Farooque et al $(1996,1997)$ found that moderate and severe SCI induced a profound raise of extracellular EAA, and that moderate hypothermia $\left(30-31^{\circ} \mathrm{C}\right)$ prolonged the EAA accumulation. ${ }^{41,42}$ The mechanisms of extracellular EAA accumulation after SCI may include both increasing release from vesicles, injured cells or blood and decreasing uptake by astrocytes and neurons. ${ }^{41,43}$ Intrathecal administration of NMDA, at a dose with no effects on uninjured animals, significantly worsens recovery after SCI. ${ }^{21}$ On the basis of these findings, several investigators analyzed NMDA receptor antagonists for the treatment of experimental SCI or ischemia. MK801, a potent NMDA antagonist, has been one of the most frequently studied (Tables 3 and 4). Treatment with MK801, given $15 \mathrm{~min}$ after or $1 \mathrm{~h}$ before spinal cord contusive injury produced by the weight drop technique, significantly attenuated some of the neurochemical changes, limited the histologic damage, and improved neurologic recovery compared to saline-treated rats ${ }^{21,22,33}$ (Table 3). Similarly, administration of MK801, 10 min after compressive SCI at a dose of $5 \mathrm{mg} / \mathrm{kg}$, significantly improved motor recovery in rabbits. In photochemically induced spinal cord lesions in rats, pretreatment with MK801 at a dose of $0.5-1 \mathrm{mg} / \mathrm{kg}$ also improved functional recovery during a 2-week posttraumatic observation period. ${ }^{44}$ In contrast, Holtz and Gerdin found that MK801 at a dose of $10 \mathrm{mg} / \mathrm{kg} 60 \mathrm{~min}$ after injury (weight drop method) in rats, did not improve functional recovery during a 4-day observation period. $^{23}$ Thus, there is considerable evidence that NMDA receptors are involved in the secondary tissue damage following SCI. The inconsistent results of the effects of MK801 on SCI may be due to variations in the timing and dosage of drug administration (Table 3 ). In the present study, we chose to administer MK801 systemically with a relatively higher dose of $7.5 \mathrm{mg} / \mathrm{mg}$, at which all the animals in MK801-treated group survived well during the $4 \mathrm{~h}$ period of observation. Furthermore, considering the $1 \mathrm{~h}$ plasma half-life time of MK801 in rats, ${ }^{45}$ we treated the animals with MK801 repetitively before and after SCI, 


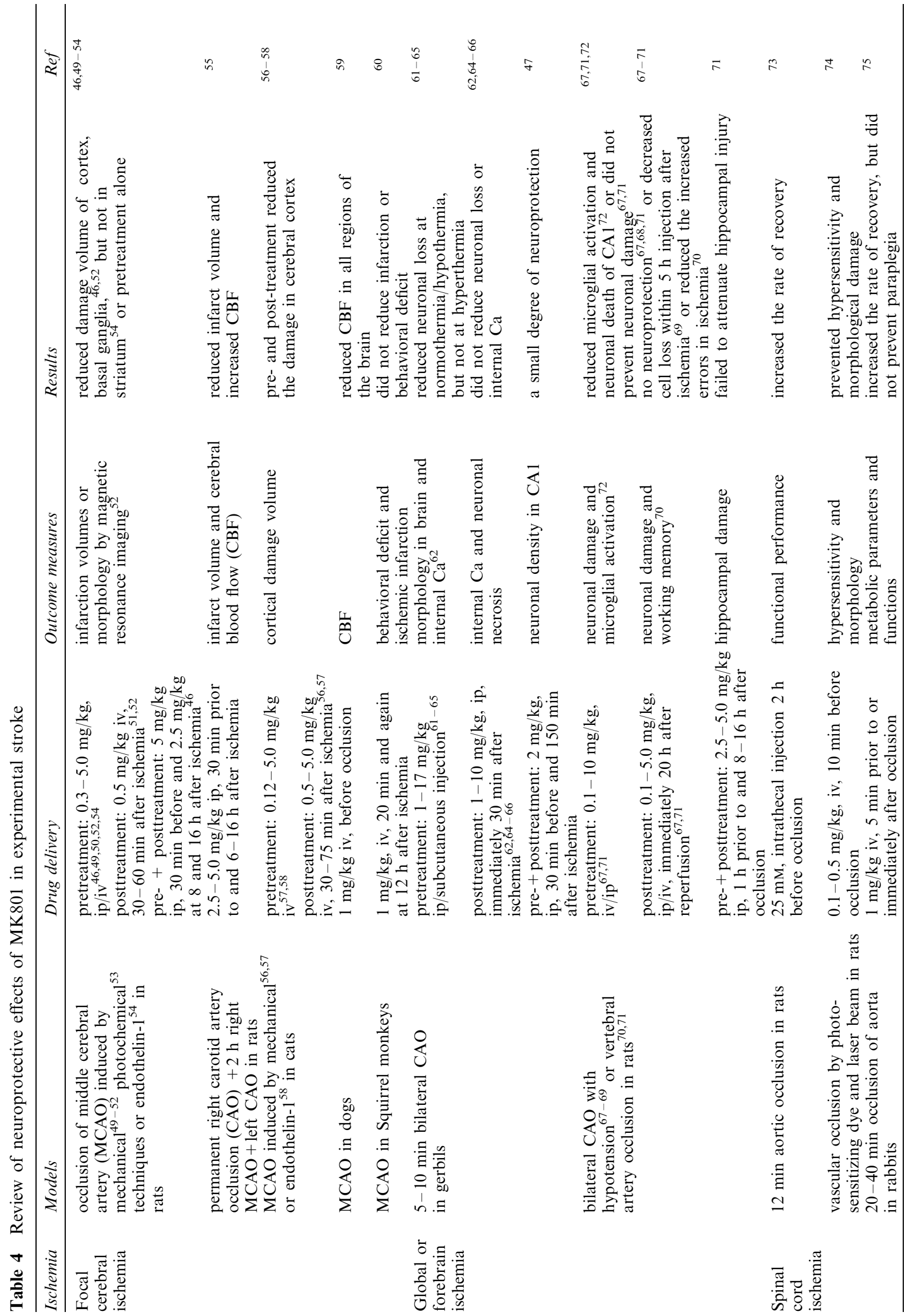


and injected the drug slowly (16 min/infusion). MK801 delivered in this way has been shown to produce neuroprotection in experimental cerebral ischemia. ${ }^{46,47}$

In the present study, we used a 21-g clip compression injury of the cord at $\mathrm{T}_{1}$, which causes a spastic paraparesis ${ }^{29}$ and produces a lesion involving the central and dorsal grey matter including the base of the dorsal columns. ${ }^{76}$ In the present experiments, 5 min after SCI, the CEPs and SSEPs were still present in most of the rats, although the amplitude of the evoked potentials was markedly decreased (Figures 2 and 4), especially the CEPs. At 5 min after SCI, there was complete disappearance of the CEPs in two rats in the MK801 group and in one rat in the saline group. SSEPs were recorded in all rats in both groups 5 min after SCI, although the signals were of very low amplitude in three rats. These findings indicate that the CEPs were more sensitive to compression injury than the SSEPs. Analysis by one-way ANOVA and paired $t$-test showed that the latency of the CEPs and SSEPs was not significantly altered between pre-and postinjury in the MK801 and saline groups, which was similar to the results of Fehlings et al. ${ }^{29}$

It is interesting to note that after SCI, the amplitude of the SSEP peaks in the MK801 group was markedly lower than that in the saline group, and the amplitude of the CEPs in the MK801 group was slightly lower than that of the saline group. Furthermore, the waveforms of both the CEPs and SSEPs differed markedly between the two groups after SCI. For example, in the SSEP recording, seven out of ten animals had only P1-N1 biphasic or P1 monophasic waveforms in the MK801 group, whereas multiphasic $\mathrm{P} 1-\mathrm{N} 1-\mathrm{P} 2$ or P1-N1-P2-N2 waveforms were present in nine out of ten animals in the saline group after SCI. These results indicate that MK801 caused significant inhibition of the evoked potentials (mainly SSEPs) during the first $4 \mathrm{~h}$ after SCI.

The mechanisms by which MK801 caused the inhibiting effects on the evoked potentials after SCI in the present study are not known. SSEPs are conducted primarily through the dorsal and dorsolateral funiculi in the rat but have components that are ventrally mediated. In contrast, the early components of the CEPs depend mainly on the integrity of the ventral spinal cord. Simultaneous recordings of both allow selective monitoring of the dorsal and ventral spinal cord. ${ }^{24}$ In the present study, the attenuation of amplitude of the SSEPs and CEPs was caused by two major factors. First, the compressive injury of the spinal cord at $\mathrm{T}_{1}$ blocked the signal transmission along afferent tracts from the peripheral to the central nervous system and induced the dysfunction of axonal conduction in the long tracts of the spinal cord. The second factor was blockade of NMDA receptors by MK801 in the somatosensory pathway, which reduced the evoked responses of neurons and/or axons at different sites in the afferent pathway including the injured spinal cord. This notion was strongly supported by the control experiments which indicate that NMDA receptor antagonist MK801 produces remarkable inhibitory effects on the sensory signal transmission in animals without SCI (Figure 6).

Our results contrast to the observation reported by Haghighi et al, who showed that Mk801 pretreatment improved the recovery of evoked potentials following a compressive SCI. ${ }^{48}$ This discrepancy is probably due to the differences in the drug dose and application procedure, and the injury model (Table 3 ). Interestingly, these authors also found that MK801 reduced the size of hemorrhage in grey matters and protected the spinal cord white matter, though NMDA receptors probably do not present on the vessels of neural tissue $^{77,78}$ and CNS white matter. ${ }^{79,80}$ However, our results are consistent with some investigations on the role of ionotropic glutamate receptor antagonists. For example, local injection of the non-NMDA receptor antagonist, 6,7-dinitro-quinoxaline-2,3-dione (DNQX), into the ventrobasal thalamic nucleus, resulted in a decrease in amplitude and an increase in latency of cortical SEPs. ${ }^{81}$ This indicates that non-NMDA receptors in the ventrobasal thalamic nucleus are involved in the transmission of cortical SEPs. In the pain model induced by formalin, treatment intrathecally with another NMDA antagonist, gamma-Dglutamyl glycine (DGG), produced profound inhibition of acute C-fibre evoked responses of the corresponding dorsal horn neurons. ${ }^{82}$ Chronic exposure to MK801 in embryos disrupts the somatotopic organization of cutaneous nerve projections in the chick spinal cord $^{83}$ and blocks the development of hyperalgesia following experimental nerve injury. ${ }^{84}$ Also, intrathecal MK801 produced a dose-dependent reduction of tactile hyperesthesia in a peripheral neuropathic pain model in rats. ${ }^{85}$ These findings are consistent with the hypothesis that blockade of glutamate neurotransmission by MK801 inhibits the flow of information along multisynaptic sensory pathways. ${ }^{86}$

Another possible mechanism for the dampening effect of MK801 on the evoked potentials was the lowering of MAP since hypotension itself may induce reduction in the evoked potential amplitude. ${ }^{87,88}$ In the MK801 group, MAP was much lower than in the saline group after SCI, especially 5 min postinjury (47 and $87 \mathrm{mmHg}$ respectively, Figure 1). A similar decline in MAP after the administration of MK801 has also been observed by other authors, ${ }^{21,33,46,89}$ though even in the presence of hypotension some found that MK801 improved functional recovery after SCI or reduced the cortical damage after focal cerebral ischemia. The mechanism of hypotension caused by SCI is due to interruption of sympathetic fibers and myocardial dysfunction. ${ }^{36}$ The hypotension induced by systemic administration of MK801 probably contributed to the blockage of NMDA receptors in the cardiovascular regulating centers. Accumulating evidence suggests that synaptic activation of NMDA receptors in the nucleus of the tractus solitarius, rostral and caudal ventrolateral medulla and spinal 
cord plays a key role in neural transmission of cardiovascular information in the central nervous system. $^{90}$ For example, local administration of MK801 in the area postrema or medial nucleus of the tractus solitarius effectively blocked NMDAinduced cardiovascular responses. ${ }^{91}$ Intrathecal injection of NMDA receptor agonists had independent effects on heart rate and blood pressure, and these effects were blocked by the NMDA receptor antagonist, 2-amino-5-phosphonovaleric acid (AP5). ${ }^{92,93}$

Acute SCI causes immediate mechanical damage to the microvasculature of the cord followed by a secondary injury to the vessels, such as vasospasm, the combination of which produces spinal cord ischemia which may be progressive. ${ }^{8,37}$ After acute cord clip compression injury in the rat, the decrease in regional SCBF at the injury site begins almost immediately and continues for at least $24 \mathrm{~h}$. In the rat, there is a direct linear dose response relationship between the severity of injury as represented by clip force and the ischemic response. ${ }^{94}$ In the present study, SCBF decreased from the pre-injury values of 71.8 and $76.3 \mathrm{ml} / \mathrm{min} / 100 \mathrm{~g}$ tissue to 38.3 and $37.5 \mathrm{ml} /$ $\mathrm{min} / 100 \mathrm{~g}$ tissue in the two groups, respectively, after the $21 \mathrm{~g}$ clip cord compression injury during the $4 \mathrm{~h}$ period of observation (Table 2). However, there was no improvement in regional SCBF in the MK801 group. This result is similar to other studies published recently which showed no improvement in posttraumatic SCBF with MK801. ${ }^{23,33}$ In addition, after intrathecal administration of 3-(2-carboxypiperazin-4yl) propyl-1-phosphoric acid (CPP), another glutamate antagonist, there was no change in SCBF compared with a saline control group in normal rats. ${ }^{95}$ These findings are consistent with the observations that NMDA receptors have not been found in cerebral microvessels ${ }^{77}$ and that NMDA agonists have no effect on cerebrovascular tone in vitro.

Spinal cord edema at the injury site develops immediately after experimental impact injury and continues for $24 \mathrm{~h}$ in rats. ${ }^{97}$ In the present study, the water content of injured cord tissue was $75.7 \%$ in the MK801 group and $77.8 \%$ in saline group, with no difference between the two groups $(P>0.05)$ although both values are higher than the normal value $(71.6 \%)$ for the rat spinal cord. ${ }^{98}$ Our result is similar to the study by Faden et al with weight-drop injury, who also found MK801 did not reduce the water content in the cord after trauma. ${ }^{21}$ In contrast, there were also reports that MK801 attenuated the water content in the injured spinal cord in plate compression model of rabbits $^{33}$ and in neoplastic compression model of rats. $^{99}$ The mechanism underlying these discrepant results is probably related to different injury models of SCI and the various methods measuring water content.

The compounds directed to NMDA receptor have produced some promising results for the treatment of experimental stroke and trauma ${ }^{1,100}$ basing on the role of this receptor in these disorders. Unfortunately, many of these potentially effective drugs have to be discontinued because of the unacceptable clinical sideeffect. ${ }^{1}$ In the present acute compressive SCI model, the inhibitory role of systemic MK801 in evoked potentials following SCI is probably related to the side effects of this agent since the same dose also produced a blocking effect in uninjured control animals. In the present study, however, the key issue is whether the inhibition of NMDA receptor antagonist after trauma is the harbinger of reduced excitotoxicity at the injury site. Following SCI, the increased extracellular glutamate may overactivate NMDA receptors and induce tissue damage via influx of $\mathrm{Ca}$ through these ion channels. Thus, the blocking effects of the systemic application of MK801 should also involve the NMDA receptors around injured spinal cord, though traumatic SCI might cause the downregulation of ionotropic glutamate receptors at injury site. ${ }^{101}$ Recently, our further investigation indicates that intramedullary injection of MK801 (30 nM) directly into injured cord statistically attenuated the amplitude of sensory evoked potentials in the same injury model, ${ }^{102}$ supporting the inhibitory role of this agent at injury site. Thus, we believe that treatment with NMDA receptor antagonist would improve the longterm conduction function of cord after the drug is washed out and would provide neuroprotection in a manner similar to $\mathrm{Na}$ channel blocker tetrodotoxin in the traumatic SCI. ${ }^{103}$

\section{Acknowledgements}

Grateful acknowledgement is made to $\mathrm{Mr}$ James Loukides for technical assistance and to the Canadian Paraplegic Association, the Medical Research Council of Canada and the Samuel Lunenfeld Foundation for financial assistance.

\section{References}

1 Muir KW, Lees KR. Clinical experience with excitatory amino acid antagonist drugs. Stroke 1995; 26: 503 - 513.

2 Choi DW. Ionic dependence of glutamate neurotoxicity. $J$ Neurosci 1987; 7: 369-379.

3 Garthwaite G, Garthwaite J. Neurotoxicity of excitatory amino acid receptor agonists in rat cerebellar slices: dependence on calcium concentration. Neurosci Lett 1986; 66: 193-198.

4 Rothman SM, Olney JW. Glutamate and the pathophysiology of hypoxic-ischemic brain damage. Ann Neurol 1986; 19: $105-$ 111.

5 Tymianski M, Charlton MP, Carlen PL, Tator CH. Source specificity of early calcium neurotoxicity in cultured embryonic spinal neurons. J Neurosci 1993; 13: 2085-2104.

6 MacDermott AB et al. NMDA-receptor activation increases cytoplasmic calcium concentration in cultured spinal cord neurones. Nature 1986; 321: 519-522.

7 Meldrum B, Garthwaite J. Excitatory amino acid neurotoxicity and neurodegenerative disease. Trends Pharmacol Sci 1990; 11: $379-387$.

8 Tator CH. Review of experimental spinal cord injury with emphasis on the local and systemic circulatory effects. Neurochirurgie 1991; 37: 291-302.

9 Happel RD et al. Ca2 +-accumulation in experimental spinal cord trauma. Brain Res 1981; 211: 476-479. 
10 Stokes BT, Fox P, Hallinden G. Extracellular calcium activity in the injured spinal cord. Exp Neurol 1983; 80: $561-572$.

11 Robledo P, Kaneko W, Ehlers CL. Combined effects of ethanol and MK 801 on locomotor activity in the rat. Pharmacol Biochem Behav 1991; 39: 513-516.

12 Young W, Yen V, Blight A. Extracellular calcium ionic activity in experimental spinal cord contusion. Brain Res 1982; 253: $105-113$.

13 Demediuk P, Daly MP, Faden AI. Effect of impact trauma on neurotransmitter and nonneurotransmitter amino acids in rat spinal cord [published erratum appears in J Neurochem 1990 Feb; 54(2): 724-725]. J Neurochem 1989; 52: 1529-1536.

14 Demopoulos HB, Flamm ES, Pietronigro DD, Seligman ML. The free radical pathology and the microcirculation in the major central nervous system disorders. Acta Physiol Scand Suppl 1980; 492: $91-119$.

15 Hall ED, Wolf DL. A pharmacological analysis of the pathophysiological mechanisms of posttraumatic spinal cord ischemia. $J$ Neurosurg 1986; 64: 951 -961.

16 Davies J, Watkins JC. Role of excitatory amino acid receptors in mono- and polysynaptic excitation in the cat spinal cord. Exp Brain Res 1983; 49: 280-290.

17 Ganong AH, Lanthorn TH, Cotman CW. Kynurenic acid inhibits synaptic and acidic amino acid-induced responses in the rat hippocampus and spinal cord. Brain Res 1983; 273: 170 174.

18 Kwak S, Nakamura R. Acute and late neurotoxicity in the rat spinal cord in vivo induced by glutamate receptor agonists. $J$ Neurol Sci 1995; 129 (Suppl): 99 - 103

19 Monaghan DT, Cotman CW. Distribution of N-methyl-Daspartate-sensitive $\mathrm{L}-[3 \mathrm{H}]$ glutamate-binding sites in rat brain. $J$ Neurosci 1985; 5: 2909-2919.

20 Craenen G, Jeftinija S, Grants I, Lucas JH. The role of excitatory amino acids in hypothermic injury to mammalian spinal cord neurons. J Neurotrauma 1996; 13: 809-818.

21 Faden AI, Lemke M, Simon RP, Noble LJ. N-methyl-Daspartate antagonist MK801 improves outcome following traumatic spinal cord injury in rats: behavioral, anatomic, and neurochemical studies. J Neurotrauma 1988; 5: $33-45$.

22 Gomez-Pinilla F, Tram H, Cotman CW, Nieto-Sampedro M. Neuroprotective effect of MK-801 and U-50488H after contusive spinal cord injury. Exp Neurol 1989; 104: 118-124.

23 Holtz A, Gerdin B. MK801, an OBS N-methyl-D-aspartate channel blocker, does not improve the functional recovery nor spinal cord blood flow after spinal cord compression in rats. Acta Neurol Scand 1991; 84: $334-338$

24 Hurlbert RJ, Koyanagi I, Tator CH. Sensory evoked potentials for selective monitoring of the rat spinal cord: a cerebellar evoked potential to assess ventral cord integrity. J Neurotrauma 1993; 10: $181-200$.

25 Fehlings MG, Tator $\mathrm{CH}$, Linden RD. The effect of nimodipine and dextran on axonal function and blood flow following experimental spinal cord injury. J Neurosurg 1989; 71: $403-$ 416.

26 Fehlings MG, Tator $\mathrm{CH}$, Linden RP, Piper IR. Motor and somatosensory evoked potentials recorded from the rat. Electroencephalogr Clin Neurophysiol 1988; 69: 65-78.

27 Perot Jr PL, Vera CL. Scalp-recorded somatosensory evoked potentials to stimulation of nerves in the lower extremities and evaluation of patients with spinal cord trauma. Ann NY Acad Sci 1982; 388: $359-368$

28 Young W. Somatosensory evoked potentials (SEP) in spinal cord injury. In: Schramm J, Jones SJ (eds). Spinal Cord Monitoring. Springer-Verlag: Berlin 1985, pp 127-142.

29 Fehlings MG, Tator $\mathrm{CH}$, Linden RD. The relationships among the severity of spinal cord injury, motor and somatosensory evoked potentials and spinal cord blood flow. Electroencephalogr Clin Neurophysiol 1989; 74: 241 - 259.

30 Martin DL. Synthesis and release of neuroactive substances by glial cells. Glia 1992; 5: $81-94$.

31 Lo EH, Sun GH, Steinberg GK. Effects of NMDA and calcium channel antagonists on regional cerebral blood flow. Neurosci Lett 1991; 131: 17-20
32 Nehls DG, Park CK, MacCormack AG, McCulloch J. The effects of N-methyl-D-aspartate receptor blockade with MK801 upon the relationship between cerebral blood flow and glucose utilisation. Brain Res 1990; 511: 271 - 279 .

33 Yanase M, Sakou T, Fukuda T. Role of N-methyl-D-aspartate receptor in acute spinal cord injury. J Neurosurg 1995; 83: $884-$ 888

34 Rivlin AS, Tator $\mathrm{CH}$. Effect of duration of acute spinal cord compression in a new acute cord injury model in the rat. Surg Neurol 1978; 10: $38-43$

35 Koyanagi I, Tator $\mathrm{CH}$. The effects of cortical stimulation, anesthesia and recording site on somatosensory evoked potentials in the rat. Electroencephalogr Clin Neurophysiol 1996; 101: $534-542$.

36 Guha A, Tator CH, Rochon J. Spinal cord blood flow and systemic blood pressure after experimental spinal cord injury in rats. Stroke 1989; 20: $372-377$.

37 Tator CH. Ischemia as a secondary neural injury. In: Salzman SK, Faden AI (eds). The Neurobiology of Central Nervous System Trauma. Oxford University Press: New York 1994, pp $209-215$

38 Liu D, Thangnipon W, McAdoo DJ. Excitatory amino acids rise to toxic levels upon impact injury to the rat spinal cord. Brain Res 1991; 547: $344-348$

39 Panter SS, Yum SW, Faden AI. Alteration in extracellular amino acids after traumatic spinal cord injury [see comments]. Ann Neurol 1990; 27: $96-99$.

40 Simpson Jr RK, Robertson CS, Goodman JC. Spinal cord ischemia-induced elevatiaon of amino acids: extracellular measurement with microdialysis. Neurochem Res 1990; 15: $635-639$

41 Farooque M, Hillered L, Holtz A, Olsson Y. Changes of extracellular levels of amino acids after graded compression trauma to the spinal cord: an experimental study in the rat using microdialysis. J Neurotrauma 1996; 13: 537-548.

42 Farooque M, Hillered L, Holtz A, Olsson Y. Effects of moderate hypothermia on extracellular lactic acid amino acids after severe compression injury of rat spinal cord. $J$ Neurotrauma 1997; 14: $63-69$.

43 Lipton SA et al. A redox-based mechanism for the neuroprotective and neurodestructive effects of nitric oxide and related nitroso-compounds [see comments]. Nature 1993; 364: 626632.

44 Hao JX et al. Protective effect of the NMDA antagonist MK801 on photochemically induced spinal lesions in the rat. Exp Neurol 1992; 118: $143-152$.

45 Hucker HB et al. Disposition and metabolism of (+)-5-methyl10,11-dihydro-5H-dibenzo[a,d] cyclohepten-5,10-imine in rats, dogs, and monkeys. Drug Metab Dispos 1983; 11: $54-58$.

46 Dirnagl U, Tanabe J, Pulsinelli W. Pre- and post-treatment with MK-801 but not pretreatment alone reduces neocortical damage after focal cerebral ischemia in the rat. Brain Res 1990; 527: $62-68$

47 Hicks CA et al. Evaluation of glycine site antagonists of the NMDA receptor in global cerebral ischemia. Brain Res 1999; 819: $65-74$.

48 Haghighi SS, Johnson GC, de Vergel CF, Vergel Rivas BJ. Pretreatment with NMDA receptor antagonist MK801 improves neurophysiological outcome after an acute spinal cord injury. Neurol Res 1996; 18: 509-515.

49 Sarraf-Yazdi $\mathrm{S}$ et al. Relative neuroprotective effects of dizocilpine and isoflurane during focal cerebral ischemia in the rat. Anesth Analg 1998; 87: 72-78.

50 Butcher SP et al. Neuroprotective actions of FK506 in experimental stroke: in vivo evidence against an antiexcitotoxic mechanism. J Neurosci 1997; 17: 6939-6946.

51 Herz RC, Kasbergen CM, Versteeg DH, De Wildt DJ. The effect of the adrenocorticotropin-(4-9) analogue, ORG 2766, and of dizolcipine (MK-801) on infarct volume in rat brain. Eur $J$ Pharmacol 1998; 346: $159-165$. 
52 Lo EH et al. Pharmacologic reversal of acute changes in diffusion-weighted magnetic resonance imaging in focal cerebral ischemia. J Cereb Blood Flow Metab 1994; 14: 497 603.

53 Takamatsu H, Kondo K, Ikeda Y, Umemura K. Neuroprotective effects depend on the model of focal ischemia following middle cerebral artery occlusion. Eur J Pharmacol 1998; 362: $137-142$.

54 Sharkey J, Butcher SP, Kelly JS. Endothelin-1 induced middle cerebral artery occlusion: pathological consequences and neuroprotective effects of MK801. J Auton Nerv Syst 1994; 49 Suppl: S177-S185.

55 Buchan AM, Slivka A, Xue D. The effect of the NMDA receptor antagonist MK-801 on cerebral blood flow and infarct volume in experimental focal stroke. Brain Res 1992; 574: 171-177.

56 Miyabe $\mathrm{M}$ et al. Comparative analysis of brain protection by $\mathrm{N}$ methyl-D-aspartate receptor antagonists after transient focal ischemia in cats. Crit Care Med 1997; 25: 1037-1043.

$57 \mathrm{McCulloch} \mathbf{J}$ et al. Glutamate receptor antagonists in experimental focal cerebral ischaemia. Acta Neurochir Suppl 1993; 57: $73-79$.

58 Dawson DA, Graham DI, McCulloch J, Macrae IM. Antiischaemic efficacy of a nitric oxide synthase inhibitor and a $\mathrm{N}$ methyl-D-aspartate receptor antagonist in models of transient and permanent focal cerebral ischaemia. Br J Pharmacol 1994; 113: $247-253$.

59 Robertson SC, Wetjen NM, Beer BJ, Loftus CM. Pre- and postischemic effects of the NMDA receptor antagonist dizocilpine maleate (MK-801) on collateral cerebral blood flow. J Neurosurg 1997; 87: $927-933$.

60 Auer RN et al. Postischemic therapy with MK-801 (dizocilpine) in a primate model of transient focal brain ischemia. Mol Chem Neuropathol 1996; 29: $193-210$.

61 Hoffman CA, Boast CA. Neuroprotection by MK-801 in temperature maintained gerbils. Brain Res Bull 1995; 38: $405-409$.

62 Nakamura K, Hatakeyama T, Furuta S, Sakaki S. The role of early $\mathrm{Ca} 2+$ influx in the pathogenesis of delayed neuronal death after brief forebrain ischemia in gerbils. Brain Res 1993; 613: $181-192$

63 Hayward NJ, McKnight AT, Woodruff GN. Brain temperature and the neuroprotective action of enadoline and dizocilpine in the gerbil model of global ischaemia. Eur J Pharmacol 1993; 236: $247-253$

64 Hara H, Onodera H, Kogure K. Effects of hyperthermia on the effectiveness of MK-801 treatment in the gerbil hippocampus following transient forebrain ischemia. Brain Res Bull 1992; 29: $659-665$.

65 Warner MA, Neill KH, Nadler JV, Crain BJ. Regionally selective effects of NMDA receptor antagonists against ischemic brain damage in the gerbil. J Cereb Blood Flow Metab 1991; 11: $600-610$

66 Sheardown MJ, Suzdak PD, Nordholm L. AMPA, but not NMDA, receptor antagonism is neuroprotective in gerbil global ischaemia, even when delayed 24 h. Eur J Pharmacol 1993; 236: $347-353$.

67 Nellgard B, Gustafson I, Wieloch T. Lack of protection by the $\mathrm{N}$-methyl-D-aspartate receptor blocker dizocilpine (MK-801) after transient severe cerebral ischemia in the rat. Anesthesiology 1991; 75: 279-287.

68 Nellgard B, Wieloch T. Postischemic blockade of AMPA but not NMDA receptors mitigates neuronal damage in the rat brain following transient severe cerebral ischemia. J Cereb Blood Flow Metab 1992; 12: 2-11.

69 Swan JH, Meldrum BS. Protection by NMDA antagonists against selective cell loss following transient ischemia. J Cereb Blood Flow Metab 1990; 10: 343 - 351.

70 Ohno M, Yamamoto T, Ueki S, Watanabe S. Protection by Nmethyl-D-aspartate receptor antagonists against impairment of working memory in rats following transient cerebral ischemia. Neurosci Lett 1992; 138: $1-4$
71 Buchan A, Li H, Pulsinelli WA. The N-methyl-D-aspartate antagonist, MK-801, fails to protect against neuronal damage caused by transient, severe forebrain ischemia in adult rats. $J$ Neurosci 1991; 11: 1049 - 1056.

72 Streit WJ, Morioka T, Kalehua AN. MK-801 prevents microglial reaction in rat hippocampus after forebrain ischemia. Neuroreport 1992; 3: 146-148.

73 Follis $\mathrm{F}$ et al. NMDA receptor blockade and spinal cord ischemia due to aortic crossclamping in the rat model. Can $J$ Neurol Sci 1994; 21: $227-232$.

74 Hao JX et al. The excitatory amino acid receptor antagonist MK-801 prevents the hypersensitivity induced by spinal cord ischemia in the rat. Exp Neurol 1991; 113: 182-191.

75 Danielisova V, Chavko M. Comparative effects of the Nmethyl-D-aspartate antagonist MK-801 and the calcium channel blocker KB-2796 on neurologic and metabolic recovery after spinal cord ischemia. Exp Neurol 1998; 149: 203-208.

76 Fehlings MG, Tator CH, Linden RD, Piper IR. Motor evoked potentials recorded from normal and spinal cord-injured rats. Neurosurgery 1987; 20: $125-130$.

77 Beart PM, Sheehan KA, Manallack DT. Absence of N-methylD-aspartate receptors on ovine cerebral microvessels. J Cereb Blood Flow Metab 1988; 8: 879-882.

78 Morley $\mathrm{P}$ et al. Evidence that functional glutamate receptors are not expressed on rat or human cerebromicrovascular endothelial cells. J Cereb Blood Flow Metab 1998; 18: 396-406.

79 Matute C, Sanchez-Gomez MV, Martinez-Millan L, Miledi R. Glutamate receptor-mediated toxicity in optic nerve oligodendrocytes. Proc Natl Acad Sci USA 1997; 94: 8830-8835.

80 Stys PK. Anoxic and ischemic injury of myelinated axons in CNS white matter: from mechanistic concepts to therapeutics. $J$ Cereb Blood Flow Metab 1998; 18: 2-25.

81 Block F, Schwarz M, Sontag KH. Non-NMDA-mediated transmission of somatosensory-evoked potentials in the rat thalamus. Brain Res Bull 1993; 31: 449-454.

82 Haley JE, Sullivan AF, Dickenson AH. Evidence for spinal Nmethyl-D-aspartate receptor involvement in prolonged chemical nociception in the rat. Brain Res 1990; 518: 218-226.

83 Mendelson B. Chronic embryonic MK-801 exposure disrupts the somatotopic organization of cutaneous nerve projections in the chick spinal cord. Brain Res Dev Brain Res 1994; 82: 152 166 .

84 Davar G et al. MK-801 blocks the development of thermal hyperalgesia in a rat model of experimental painful neuropathy. Brain Res 1991; 553: $327-330$

85 Lee YW, Yaksh TL. Analysis of drug interaction between intrathecal clonidine and MK-801 in peripheral neuropathic pain rat model. Anesthesiology 1995; 82: $741-748$.

86 Dai H, Carey RJ. The NMDA antagonist MK-801 can impair attention to exteroceptive stimuli. Behav Brain Res 1994; 62: $149-156$.

87 Sato M, Pawlik G, Umbach C, Heiss WD. Comparative studies of regional CNS blood flow and evoked potentials in the cat Effects of hypotensive ischemia on somatosensory evoked potentials in cerebral cortex and spinal cord. Stroke 1984; 15: $97-101$

88 Yeoman PM, Gibson MJ, Hutchinson A, Crawshaw C, Bradshaw K, Beattie A. Influence of induced hypotension and spinal distraction on feline spinal somatosensory evoked potentials. Br J Anaesth 1989; 63: $315-320$.

89 Kane PJ, Cook S, Chambers IR, Mendelow AD. Cerebral oedema following intracerebral haemorrhage: the effect of the NMDA receptor antagonists MK-801 and D-CPPene. Acto Neurochir Suppl 1994; 60: 561 - 563

90 Gordon FJ. Excitatory amino acid receptors in central cardiovascular regulation. Clin Exp Hypertens 1995; 17: 81 - 90

91 Tian B, Hartle DK. Cardiovascular effects of NMDA and MK801 infusion at area postrema and mNTS in rat. Pharmacol Biochem Behav 1994; 49: 489-495. 
92 West M, Huang W. Spinal cord excitatory amion acids and cardiovascular autonomic responses. Am J Physiol 1994; 267: $\mathrm{H} 865-\mathrm{H} 873$.

93 Hong YG, Henry JL. Glutamate, NMDA and NMDA receptor antagonists: cardiovascular effects of intrathecal administration in the rat. Brain Res 1992; 569: $38-45$.

94 Tator CH, Fehlings MG. Review of the secondary injury theory of acute spinal cord trauma with emphasis on vascular mechanisms [see comments]. J Neurosurg 1991; 75: 15-26.

95 Kristensen JD, Karlsten R, Gordh T. Laser-Doppler evaluation of spinal cord blood flow after intrathecal administration of an N-methyl-D-aspartate antagonist in rats. Anesth Analg 1994; 78: $925-931$.

96 Hardebo JE, Wieloch T, Kahrstrom J. Excitatory amino acids and cerebrovascular tone. Acta Physiol Scand 1989; 136: $483-$ 485.

97 Yashon D, Bingham Jr WG, Faddoul EM, Hunt WE. Edema of the spinal cord following experimental impact trauma. $J$ Neurosurg 1973; 38: $693-697$.

98 Sharma HS et al. Evaluation of traumatic spinal cord edema using evoked potentials recorded from the spinal epidural space. An experimental study in the rat. J Neurol Sci 1991; 102: $150-162$.
99 Siegal T, Shohami E, Lossos F. Experimental neoplastic spinal cord compression: effect of ketamine and MK-801 on edema and prostaglandins. Neurosurgery 1990; 26: $963-966$.

100 Lee JM, Zipfel GJ, Choi DW. The changing landscape of ischaemic brain injury mechanisms. Nature 1999; 399: A7-A14.

101 Grossman SD, Wolfe BB, Yasuda RP, Wrathall JR. Alterations in AMPA receptor subunit expression after experimental spinal cord contusion injury. J Neurosci 1999; 19: 5711-5720.

$102 \mathrm{Li} \mathrm{S}$, Tator CH. NMDA and non-NMDA receptor antagonists block local glutamate excitatory transmission and do not relieve traumatic ischemia following experimental spinal cord injury. $J$ Neurotrauma 1998; 15: 12.

103 Teng YD, Wrathall JR. Local blockade of sodium channels by tetrodotoxin ameliorates tissue loss and long-term functional deficits resulting from experimental spinal cord injury. $J$ Neurosci 1997; 17: 4359-4366. 